\title{
PEMBERDAYAAN EKONOMI MASYARAKAT MELALUI DANA DESA: SEBUAH KEBIJAKAN PEMERINTAH ACEH BARAT
}

\author{
Dinda Nurhanifa ${ }^{{ }^{*}}$, Afrizal Tjoetra ${ }^{2}$, Ikhsan ${ }^{3}$ \\ ${ }^{1}$ Jurusan Ilmu Administrasi Negara \\ Universitas Teuku Umar \\ Email: dinda.nurhanifa@gmail.com \\ 2Jurusan Sosiologi \\ Universitas Teuku Umar \\ Email: afrizaltjoetra@utu.ac.id \\ 3 Jurusan Ilmu Administrasi Negara \\ Universitas Teuku Umar \\ Email: ikhsan.baharudin@utu.ac.id
}

\begin{abstract}
Abstrak
Penelitian ini bertujuan untuk mengetahui pelaksanaan Peraturan Bupati Aceh Barat Nomor 27 Tahun 2017 tentang Pedoman Pemberdayaan Ekonomi Masyarakat melalui Dana Desa di Kecamatan Johan Pahlawan. Penelitian ini menggunakan pendekatan kualitatif dengan metode deskriptif dan menggunakan teori Van Metter dan Van Horn. Hasil penelitian menunjukkan bahwa pelaksanaan Peraturan Bupati Aceh Barat Nomor 27 Tahun 2017 tentang Pedoman Pemberdayaan Ekonomi Masyarakat melalui Dana Desa di Kecamatan Johan Pahlawan terutama pada Gampong Leuhan, Gampong Padang Seurahet, dan Gampong Blang Beurandang sudah dilaksanakan sesuai dengan ketentuan Peraturan Bupati Aceh Barat Nomor 27 Tahun 2017. Hal ini dibuktikan dengan terlaksananya 2 (dua) indikator kebijakan, yaitu penyaluran dana bantuan pemberdayaan dari perangkat gampong kepada masyarakat sesuai dengan standar dan tujuan kebijakan, serta sumber daya manusia dan anggarannya sudah memadai sehingga respon dari masyarakat sangat antusias terhadap kegiatan pemberdayaan ekonomi masyarakat melalui dana desa. Namun didalam pelaksanaan Peraturan Bupati Aceh Barat Nomor 27 Tahun 2017 masih terdapat 4 (empat) kendala yaitu kurangnya sosialisasi kepada masyarakat sehingga masyarakat gampong kurang memahami terhadap standar, tujuan dan mekanisme serta kurangnya komunikasi dan koordinasi antara agen pelaksana pemberdayaan ekonomi pada tahun 2017 dengan pemerintahan gampong yang sekarang, kemudian pembinaan dan pengawasan yang tidak dilakukan secara menyeluruh oleh pelaksana dan proses verifikasi tidak maksimal.
\end{abstract}

Kata kunci: dana desa; Ekonom;, Masyarakat; Pelaksanaan; Pemberdayaan

\section{COMMUNITY ECONOMIC EMPOWERMENT THROUGH VILLAGE FUNDS: POLICY OF WEST ACEH GOVERNMENT}

\begin{abstract}
This study aims to determine the implementation of West Aceh Regent Regulation No. 27 of 2017 concerning Guidelines for Community Economic Empowerment through Village Funds in Johan Pahlawan District. This study uses a qualitative approach with descriptive methods and uses Van Metter and Van Horn theories. The results showed that the implementation of West Aceh Regent Regulation No. 27 of 2017 concerning Guidelines for Community Economic Empowerment through Village Funds in Johan Pahlawan Subdistrict especially at Leuhan Village, Padang Seurahet Village, and Blang Beurandang Village had been carried out in accordance with
\end{abstract}


the provisions of the West Aceh Regent Number 27 Year 2017. This is evidenced by the implementation of 2 (two) policy indicators, namely the distribution of empowerment assistance funds from the village to the community in accordance with the standards and policy objectives, as well as adequate human resources and budgets so that the response of the community is very enthusiastic about the activities of community economic empowerment through village funds. However, in the implementation of West Aceh Regent Regulation No. 27 of 2017 there are still 4 (four) obstacles, namely lack of socialization to the community so that the village community does not understand the standards, goals and mechanisms as well as the lack of communication and coordination between implementing agents for economic empowerment in 2017 with the village government now, then the guidance and supervision that is not carried out thoroughly by the implementers and the verification process is not optimal.

Keywords: village funds; community; Implementation; Empowerment

\section{PENDAHULUAN}

Penelitian ini membahas tentang pelaksanaan Peraturan Bupati Aceh Barat Nomor 27 Tahun 2017 tentang Pedoman Pemberdayaan Ekonomi Masyarakat melalui Dana Desa. Chamber Pada tahun 1995 berpendapat bahwa pemberdayaan masyarakat merupakan nilai-nilai masyarakat yang harus dibangun sebagai perwujudan paradigma baru di dalam konsep pembangunan ekonomi yang bersifat people centered, participatory, empowerment and sustainable. Chamber lebih lanjut menjelaskan bahwa konsep pemberdayaan masyarakat tidak semata-mata untuk memenuhi kebutuhan dasar masyarakat saja akan tetapi usaha yang dilakukan untuk memperoleh alternatif lain demi terwujudnya pertumbuhan ekonomi lokal(Chambers, 1995).

Menurut Edi Suharto (2005) secara konseptual kata pemberdayaan atau pemberkuasaan berasal dari kata "Power" yang artinya kekuatan, kekuasaan atau keberdayaan. Pemberdayaan dapat meningkatkan kapasitas seseorang atau sekelompok orang terutama kelompok masyarakat yang rentan dan lemah dalam memenuhi kebutuhan hidupnya sehingga mereka mempunyai kekuatan dan kemampuan memperoleh barangbarang dan jasa yang mereka butuhkan termasuk menjangkau sumber-sumber produktif yang digunakan untuk meningkatkan pendapatannya. Pemberdayaan masyarakat sebagai bentuk pembangunan berakar kerakyatan adalah usaha yang dilakukan untuk meningkatkan harkat dan martabat masyarakat yang masih terperangkap dalam kemiskinan dan keterbelakangan (Suharto, 2005).

Sepanjang sejarah bangsa Indonesia tidak pernah lepas dari persoalan kemiskinan. Kemiskinan terus terjadi dan sulit untuk terselesaikan. Pada tahun 2011 Kementerian Sosial menjelaskan bahwa kemiskinan ditandai dengan terjadinya pengangguran, keterbelakangan dan ketidak berdayaan. Kesulitan yang dialami Indonesia dalam menanggulangi masalah kemiskinan ialah masyarakat Indonesia mayoritasnya tergolong kedalam kemiskinan kronis (chronic 
poverty) atau kemiskinan struktural.

Salah satunya Penyandang Masalah Kesejahteraan Sosial (PMKS) merupakan kelompok masyarakat yang dikategorikan kedalam kemiskinan structural (Purwanto, 2007).

Berbagai persoalan kemiskinan diatas tentu saja akan membuat jutaan anak-anak Indonesia tidak dapat mengenyam pendidikan dengan layak, sulit untuk membiayai kesehatan, meningkatnya angka pengangguran akibat terbatasnya lapangan pekerjaan dan jumlah penduduk yang semakin bertambah.

Di Provinsi Aceh khususnya Aceh Barat, tidak lepas juga dengan permasalahan kemiskinan yang bisa dilihat melalui Badan Pusat Statistik Aceh Barat tahun 2018 tentang garis kemiskinan. Garis kemiskinan di Aceh Barat mengalami peningkatan setiap tahunnya. Pada tahun 2016, garis kemiskinan dari 441.909 ribu rupiah per kapita per bulan menjadi 446.614 ribu rupiah pada tahun 2017, dikarenakan adanya inflasi. Jika rata-rata anggota rumah tangga terdapat 4 orang anggota seperti Ayah, Ibu dan 2 orang anak maka rumah tangga tersebut pengeluaran-nya sebulan berada dibawah 446.614 ribu rupiah maka akan dianggap miskin dan terdapat empat orang pula penduduk miskin. Seharusnya jika 4 orang dalam satu keluarga maka harus memperoleh penghasilan minimal sebesar 1.786.456 ribu rupiah. Dari angka garis kemiskinan tersebut, penduduk yang berada dibawah garis kemiskinan berjumlah 40.720 jiwa dari 193.791 jumlah penduduk di Kabupaten Aceh Barat atau setara 20,28 persen penduduk miskin. Jika kita melihat Badan Pusat Statistik angka dua puluhan persen tersebut masih terlalu besar jika dibandingkan dengan kabupaten terdekat. Seperti Kabupaten Simeuleu (19.93 persen), Nagan Raya (19.25 persen), dan Aceh Jaya (15.01 persen), untuk itu Pemerintah Daerah Kabupaten Aceh Barat harus berusaha keras untuk menurunkan angka ini.

Selain kemiskinan Fenomena Pengangguran di Aceh Barat menurut Badan Pusat statistik Aceh Barat tahun 2018 mengemukakan bahwa pertambahan jumlah penduduk Kabupaten Aceh Barat angkatan kerja tanpa diiringi dengan pertambahan lapangan kerja yang memadai menyebabkan jumlah pengangguran. Pada tahun 2015 kembali bertambah menjadi 5.975 jiwa dari tahun sebelumnya 2014 sebanyak 4.887 Jiwa. Jadi Angka pengangguran di Kabupaten Aceh Barat tahun 2015 dengan angkatan kerja 88.306 jiwa berjumlah 5.975 jiwa atau setara dengan 6,77 persen. Pada tahun 2016 seluruh Indonesia tidak melakukan pendataan. Di Tahun 2017 angka pengangguran mengalami penurunan sebesar 0.5 persen menjadi 6,20 persen atau setara dengan 5.428 dari 145.164 jumlah angkatan kerja namun angka pengangguran tidak turun secara signifikan.

Melihat fenomena diatas pemerintah sebagai pemegang otoritas 
publik perlu mengeluarkan sebuah kebijakan atau keputusan yang berdampak positif bagi orang banyak dalam hal mengatasi problemaproblema kemiskinan, salah satunya pemerintah Kabupaten Aceh Barat mengeluarkan suatu kebijakan di bidang pemberdayaan ekonomi masyarakat dimana Pemerintah Kabupaten Aceh Barat mempunyai tekad yang kuat dalam aspek penanggulangan kemiskinan khususnya dalam pengarusutamaan kebijakan (mainstreaming of police) sebagai langkah strategis melalui berbagai program yang berorientasi kepada percepatan kesejahteraan warga serta penciptaan lapangan kerja.

Pemerintah Kabupaten Aceh Barat mengeluarkan sebuah Peraturan Bupati Aceh Barat Nomor 27 Tahun 2017 tentang Pedoman Pemberdayaan Ekonomi Masyarakat melalui Dana Desa. Sasaran dari pemberdayaan ekonomi masyarakat ini adalah kelompok masyarakat miskin, kaum disabilitas atau cacat fisik, kaum perempuan, masyarakat yang belum memperoleh pekerjaan tetap dan masyarakat yang sudah memiliki usaha kemudian tujuan dari Peraturan Bupati ini adalah untuk meningkatkan pendapatan masyarakat desa, menurunkan jumlah penduduk miskin, menurunkan angka pengangguran, meningkatkan pengetahuan, keterampilan, sikap, dan perilaku masyarakat, meningkatkan produktivitas dan daya saing usaha masyarakat serta mempersiapkan kader sumber daya manusia yang handal dan terlatih.

Implementasi Peraturan Bupati ini telah dilaksanakan oleh seluruh Kecamatan hingga di tingkat Gampong yang ada di Kabupaten Aceh Barat. Kecamatan Johan Pahlawan adalah Kecamatan yang berada di Kabupaten Aceh Barat yang memiliki 21 Gampong. Gampong merupakan penyebutan nama lain dari pada desa yang telah diberikan hak otonomi dalam menyelenggarakan urusan rumah tangganya sendiri. Kecamatan Johan Pahlawan juga memiliki jumlah penduduk terbanyak di Kabupaten Aceh Barat mencapai 65.197 jiwa atau setara dengan 32,33 persen berdasarkan Badan Pusat Statistik Aceh Barat Tahun 2018. Kecamatan Johan Pahlawan selain jumlah penduduk terbanyak juga salah satu kecamatan tertinggi dengan angka kemiskinan mencapai 4.032 dari 19.648 Kepala Keluarga. Berdasarkan pengamatan penelitian yang dilakukan di Dinas Sosial pada tanggal 10 Mai 2019, penduduk miskin terbanyak terdapat di Gampong Leuhan dengan 242 Kepala Keluarga, Kedua di Gampong Padang Seurahet 185 Kepala Keluarga dan di Gampong Blang Beurandang 144 Kepala Keluarga. Tiga Gampong tersebut merupakan penduduk terbanyak yang dikategorikan kedalam penduduk miskin dari 21 Gampong di Kecamatan Johan Pahlawan Kabupaten Aceh Barat sehingga pemberdayaan ekonomi masyarakat yang diselenggarakan oleh pemerintah Gampong dimaksudkan 
sebagai salah satu langkah strategis untuk memenuhi penggunaan prioritas dana Gampong sesuai arah kebijakan pemerintah kabupaten demi mewujudkan masyarakat yang sejahtera dan mandiri dibidang ekonomi.

$$
\text { Kegiatan pemberdayaan }
$$

ekonomi masyarakat melalui dana desa merupakan kebijakan yang menggunakan pendekatan top down (Harahap, 2012). Artinya kegiatan tersebut dibuat oleh pemerintah daerah dalam hal ini Dinas Pemberdayaan Masyarakat Gampong Kabupaten Aceh Barat. Keberhasilan kebijakan tersebut diraih apabila kognisi agen pelaksana yang baik dan mendapatkan dukungan penuh serta persetujuan para stakeholder yang terlibat dalam hal ini para agen pelaksana. Kognisi (pemahaman) para agen pelaksana sepenuhnya memahami bahwa kegiatan pemberdayaan ekonomi masyarakat merupakan kebijakan Kabupaten Aceh Barat dalam bidang pemberdayaan perekonomian yang dilaksanakan di tingkat gampong. Pemegang kendali dalam kebijakan ini adalah Dinas Pemberdayaan Masyarakat Gampong Kabupaten Aceh Barat. Terkait Respon (dukungan/persetujuan) pemerintah kabupaten, Dinas Pemberdayaan Masyarakat Gampong Kabupaten Aceh Barat, lembaga-lembaga terkait lainnya hingga pemerintah Kecamatan sangat mendukung terhadap pelaksanaan kegiatan pemberdayaan ekonomi masyarakat melalui dana gampong, harapannya Peraturan Bupati ini mampu mengurangi angka kemiskinan sehingga masyarakat lebih terperdaya, mandiri dan sejahtera secara ekonomi didalam memenuhi kebutuhan hidupnya. Kemudian peneliti melihat sudut pandang yang berbeda dari ketiga perangkat Gampong ini antara lain Gampong Leuhan, Gampong Padang Seurahet dan Gampong Leuhan sebagai pelaksana utama kegiatan pemberdayaan ditingkat gampong belum sepenuhnya memberikan dukungan terhadap kegiatan pemberdayaan ekonomi masyarakat melalui dana desa sebab kesadaran dari masyarakat dalam mengelola dan mengembalikan dana tersebut tidak ada.

Hal lainnya terjadi kecemburuan sosial sesama masyarakat dan perangkat gampong dimana timbul perseteruan diantara mereka. Perangkat gampong juga tidak ingin berurusan maupun terlibat dengan pihak yang berwajib akibat dana pemberdayaan ekonomi ketika ada pemeriksaan yang dilakukan oleh Inspektorat, Kejaksaan dan pihak berwajib lainnya.

\section{METODE}

Dalam Penelitian ini metode yang digunakan adalah metode kualitatif. Moleong berpendapat penelitian kualitatif adalah penelitian yang bermaksud untuk memahami tentang fenomena apa yang dialami oleh subjek penelitian, misalnya perilaku, persepsi, motivasi, tindakan secara holistik, dan dengan cara deskripsi berupa bentuk kata-kata dan 
bahasa, pada suatu konteks khusus yang alamiah dengan memanfaatkan berbagai metode alamiah.

Dapat ditarik kesimpulan bahwa penelitian kualitatif adalah penelitian digunakan untuk meneliti dan memahami fenomena yang dialami oleh subjek penelitian dimana peneliti merupakan instrumen kunci, teknik pengumpulan data dilakukan secara triangulasi, analisis data bersifat induktif, sehingga menghasilkan data deskriptif berupa kata-kata tertulis atau lisan dari orang- orang atau prilaku yang dapat diamati.

\section{HASIL DAN PEMBAHASAN}

Diberlakukannya Peraturan

Bupati Aceh Barat Nomor 27 tahun 2017 tentang Pedoman Pemberdayaan Ekonomi Masyarakat Melalui Dana Desa dalam Kabupaten Aceh Barat dimana pada Peraturan Bupati ini menyatakan bahwa Pemberdayaan ekonomi masyarakat diselenggarakan oleh pemerintah gampong yang dimaksudkan sebagai salah satu langkah strategis untuk memenuhi penggunaan prioritas dana desa sesuai arah kebijakan pemerintah kabupaten.

Pelaksanaan Peraturan Bupati

Aceh Barat Nomor 27 Tahun 2017 Tentang Pedoman Pemberdayaan Ekonomi Masyarakat melalui Dana Desa Di Kecamatan Johan Pahlawan pada Gampong Leuhan, Padang Seurahet dan Blang Beurandang. Pemberdaayaan ekonomi masyarakat ini adalah kegiatan yang dilaksanakan oleh pemerintah gampong untuk memenuhi kebutuhan ekonomi masyarakat gampong sesuai dengan usaha yang dijalankan atau keahlian yang dimiliki serta didukung melalui upaya meningkatkan pengetahuan dan keterampilan tersebut dalam rangka mewujudkan kemandirian dan meningkatkan kesejahteraan (Karimah, Faizatul ; Saleh, Kahirul ; Wanusmawatie, 2017).

Hal ini dapat kita lihat sebagaimana tercantum pada pasal 2 Peraturan Bupati Aceh Barat Nomor 27 Tahun 2017 yaitu: 1). Meningkatkan pendapatan masyarakat gampong 2). Menurunkan jumlah penduduk miskin 3). Menurunkan angka pengangguran 4). Meningkatkan pengetahuan, keterampilan, sikap, dan perilaku masyarakat 5). Meningkatkan produktifitas dan daya saing usaha masyarakat 6). Mempersiapkan kader sumberdaya manusia yang handal dan terlatih, dan Meningkatkan pendapatan asli gampong

Sasaran pemberdayaan ekonomi masyarakat adalah penerima manfaat dari: (a) kelompok masyarakat miskin (b) kaum disabilitas atau cacat fisik (c) kaum perempuan (d) masyarakat yang belum memiliki pekerjaan tetap dan (e) masyarakat yang telah memiliki usaha.

Pemberdayaan ekonomi masyarakat diselenggarakan berdasarkan prinsip- prinsip diantaranya yaitu: (a) berorientasi pada kebutuhan usaha, minat dan/atau kemampuan dasar yang dimiliki oleh masyarakat (b) berorientasi pada kebutuhan pengembangan potensi sumberdaya lokal (c) sistematis (d) profesional (e) 
selektif adil (g) efektif dan efesien (h) transparansi (i) akuntabel dan (j) bersih atau bebas dari korupsi, kolusi dan nepotisme.

Untuk klasifikasi besaran anggaran kegiatan tercantum dalam pasal 3 menyatakan bahwa penyelenggaran kegiatan pemberdayaan ekonomi masyarakat dilaksanakan dengan APBG yang dibiayai dari sumber dana desa dari APBN. Klasifikasi besaran anggaran kegiatan berpedoman pada peraturan bupati yang mengatur tentang dana desa serta penentuan anggaran untuk kegiatan pemberdayaan ekonomi masyarakat ditetapkan berdasarkan musyawarah perencanaan pembangunan gampong setelah mempertimbangkan kondisi masyarakat, kondisi perekonomian dan kondisi sumberdaya alam gampong yang kemudian ditetapkan dalam Qanun gampong tentang RKPG dan APBG.

Berdasarkan Pasal 4 kegiatan pemberdayaan ekonomi masyarakat terdiri dari komponen diantaranya yaitu (a) operasional kegiatan (b) pelatihan masyarakat dan (c) bantuan modal pemberdayaan ekonomi. Penganggaran dana desa pada masing-masing komponen kegiatan dari total dana desa yang dialokasikan untuk kegiatan pemberdayaan ekonomi masyarakat adalah: 1). Sekurang-kurangnya 10\% (sepuluh persen) untuk operasional kegiatan. 2). Sekurang-kurangnya 10\% (sepuluh persen) untuk pelatihan masyarakat. 3). Sebesar-besarnya $80 \%$ (delapan puluh persen) untuk bantuan modal pemberdayaan ekonomi.

Untuk modal pemberdayaan ekonomi dimuat dalam pasal 8 bahwa bantuan modal pemberdayaan ekonomi berbentuk barang kebutuhan penerima manfaat yang disediakan oleh pemerintah gampong sesuai dengan permohonan penerima manfaat dan dibeli oleh masyarakat melalui angsuran atau cicilan. Rincian kebutuhan bantuan modal pemberdayaan ekonomi terdiri dari beberapa barang yang dijual kepada masyarakat sesuai dengan kebutuhan usaha yang dijalankan oleh penerima manfaat. Angsuran atau cicilan dari masyarakat diterima oleh pemerintah gampong dan dicatat sebagai pendapatan asli gampong pada rekening lain-lain pendapatan asli desa yang sah dalam objek pendapatan dari angsuran/cicilan penjualan.

Mekanisme pemberdayaan ekonomi tertuang di dalam Peraturan Bupati Nomor 27 Tahun 2017 terdiri dari:

1. Proposal Masyarakat.

Masyarakat yang membutuhkan bantuan modal pemberdayaan ekonomi wajib mengajukan proposal kepada pemerintah gampong. Selanjutnya kelengkapan administrasi dalam proposal masyarakat paling sedikit terdiri dari (a) Permohonana kepada Keuchik, (b) Rincian kebutuhan sesuai jenis usaha dan (c) Foto lokasi usaha. Pemerintah gampong dapat menambahkan kelengkapan administrasi lainnya sesuai dengan kebutuhan dan kondisi masyarakat setempat. Berikut disajikan dalam 
Gambar 1. Alur pengajuan proposal

oleh masyarakat

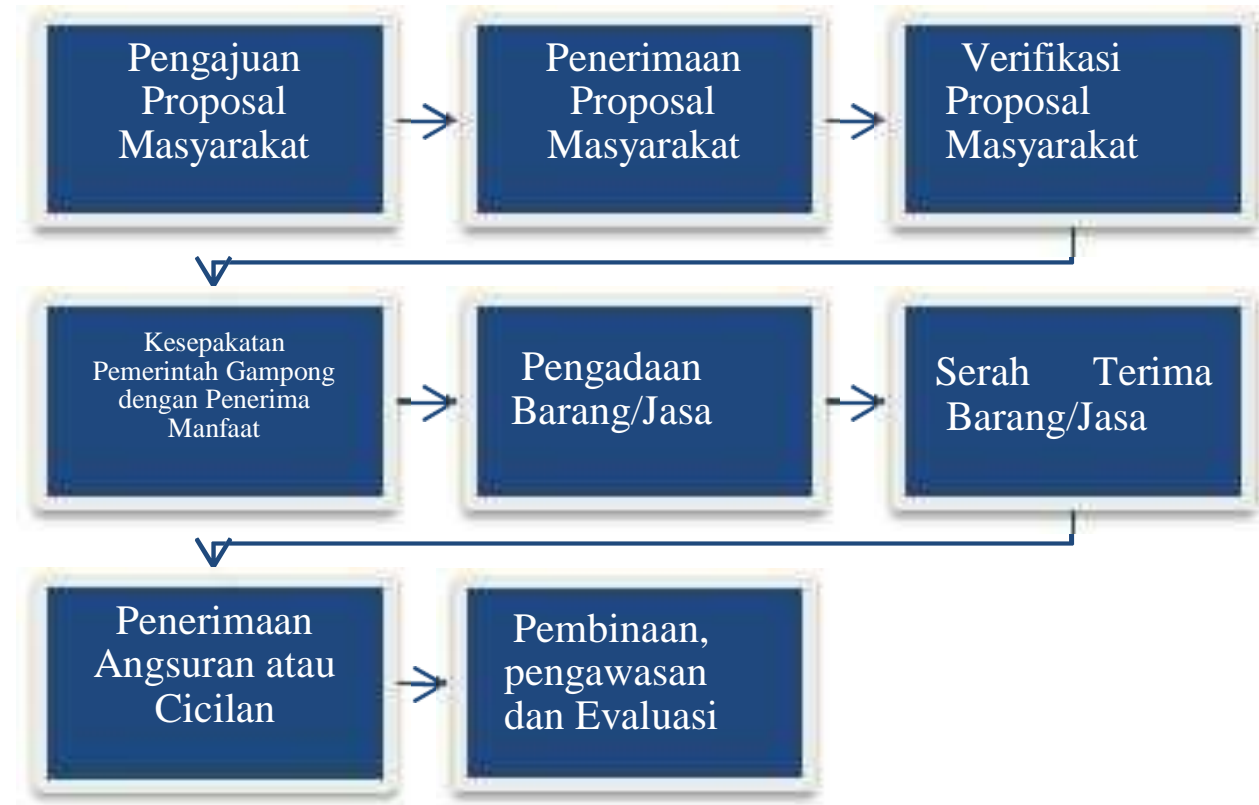

Gambar 1. Alur pengajuan proposal oleh masyarakat Sumber: Diolah Peneliti Dari Berbagai, 2019

Pengajuan proposal oleh masyarakat kepada pemerintah gampong dilakukan sebelum ditetapkannya Qanun gampong tentang RKPG dan APBG. Apabila masyarakat mengajukan proposal setelah RKPG dan APBG ditetapkan, maka pengalokasian Dana Desa untuk memenuhi kebutuhan dalam proposal tersebut dianggarkan pada perubahan RKPG dan APBG atau dianggarkan pada RKPG dan APBG tahun anggaran berikutnya sesuai dengan ketersediaan dan kemampuan anggaran pemerintah gampong.

Tim Verifikasi Pemberdayaan Ekonomi melakukan verifikasi terhadap proposal masyarakat yang diterima oleh pemerintah gampong antara lain adalah (a) kesesuaian pemohon dengan syarat-syarat prioritas penerima manfaat, (b) kesesuaian rincian kebutuhan pemohon dengan jenis usaha yang dilakukan dan (c) kesesuaian foto lokasi usaha dengan kondisi ril. Apabila terjadi perbedaan penilaian dari anggota terhadap kelayakan calon penerima manfaat, maka ketua tim verifikasi dapat melakukan voting untuk menentukan suara terbanyak terhadap proposal yang memenuhi kriteria. Proposal masyarakat yang memenuhi kriteria selanjutnya ditetapkan sebagai proposal calon penerima manfaat bantuan modal dan pemberdayaan ekonomi.

Pengajuan proposal dari masyarakat harus melampirkan kelengkapan administrasi proposal seperti surat permohonan kepada keuchik, rincian kebutuhan sesuai jenis usaha dan foto lokasi usaha kemudian persyaratan lainnya yaitu foto copy KTP 
dan foto kopi Kartu Keluarga (KK) yang diminta dari masyarakat, sehingga bantuan pemberdayaan ekonomi dapat diberikan kepada masyarakat yang membutuhkan seperti masyarakat kurang mampu dan tidak mempunyai pekerjaan serta masyarakat yang mempunyai usaha.

Terkait dengan verifikasi proposal masyarakat penerima bantuan modal pemberdayaan ekonomi dilakukan dengan tujuan menseleksi dan memastikan proposal yang diajukan oleh masyarakat sesuai dengan kriteriakriteria yang sudah ditetapkan dalam Peraturan Bupati Aceh Barat Nomor 27 Tahun 2017 agar kegiatan pemberdayaan menjadi tepat sasaran. Verifikasi yang dilakukan paling sedikit meliputi:

2. Kesepakatan Pemerintah Gampong dengan Penerima Manfaat

Berdasarkan

proposal

masyarakat yang terverifikasi, pemerintah gampong kemudian merumuskan kesepakatan dengan penerima manfaat. Kesepakatan ini terdiri atas (a) kesepakatan tentang besaran total pengembalian bantuan modal, (b) kesepakatan tentang jangka waktu angsuran atau cicilan dan (c) kesepakatan tentang besaran biaya angsuran atau cicilan. Kesepakatan dituangkan dalam berita acara kesepakatan pemberdayaan ekonomi yang ditandatangani oleh penerima manfaat dan keuchik gampong.
3. Pengadaan Barang dan Jasa

Pengadaan barang atau jasa dilakukan secara swakelola. Pengadaan barang atau jasa di gampong dilaksanakan oleh TPK yang ditetapkan dengan keputusan Keuchik yang keanggotaannya terdiri dari unsur pemerintah gampong dan unsur lembaga kemasyarakatan gampong. Barang atau jasa tersebut digunakan untuk memenuhi kebutuhan dalam rangka mendukung pelaksanaan pemberdayaan ekonomi masyarakat. Dalam melaksanakan pengadaan barang atau jasa merujuk pada standarisasi pengadaan barang atau jasa. Selanjutnya pengadaan barang dan jasa tersebut diserah terima kepada pemerintah gampong dan pemerintah gampong yang dimaksud bisa diwakilkan kepada kepala urusan yang menangani bidang kesejahteraan masyarakat.

\section{Serah Terima}

Serah terima hasil pengadaan barang atau jasa dilakukan dengan cara (a) TPK menyerah terimakan hasil pengadaan barang/jasa kepada pemerintah gampong, (b) pemerintah gampong bersama dengan tim verifikasi melakukan serah terima barang kepada penerima manfaat, (c) pemerintah gampong menyiapkan berita acara serah terima dan dokumen perjanjian dan (d) serah terima kepada penerima manfaat dilakukan setelah dokumen perjanjian ditanda tangani antara pemerintah gampong dengan penerima manfaat. Pemerintah gampong mendokumentasikan dan menyimpan 
dokumen hasil serah terima barang atau jasa serta melaporkan hasil serah terima kepada keuchik.

5. Penerimaan Angsuran dan Cicilan

Penerimaan angsuran atau cicilan dapat dilakukan dengan cara Keuchik menunjuk kepala urusan kesejahteraan sosial gampong melalui keputusan keuchik sebagai pejabat penerimaan angsuran atau cicilan dan Keuchik juga dapat menunjuk pengurus BUMG sebagai penerima angsuran melalui keputusan keuchik. Pejabat penerimaan angsuran/cicilan mempunyai tugas diantaranya adalah (a) menerima angsuran/cicilan pelunasan barang dari penerima manfaat (b) mencatat angsuran/cicilan dari penerima manfaat (c) menyerahkan angsuran/cicilan pelunasan barang kepada bendahara gampong dan (d) mengadministrasikan bukti-bukti angsuran/cicilan.

Awal lahir Peraturan Bupati Aceh Barat Nomor 27 Tahun 2017 tersebut atas dasar kondisi masyarakat yang terperangkap dalam kemiskinan di tahun 2016. Berikut disajikan dalam Gambar 2. Persentase penduduk miskin di Kabupaten Aceh Barat tahun 20112017

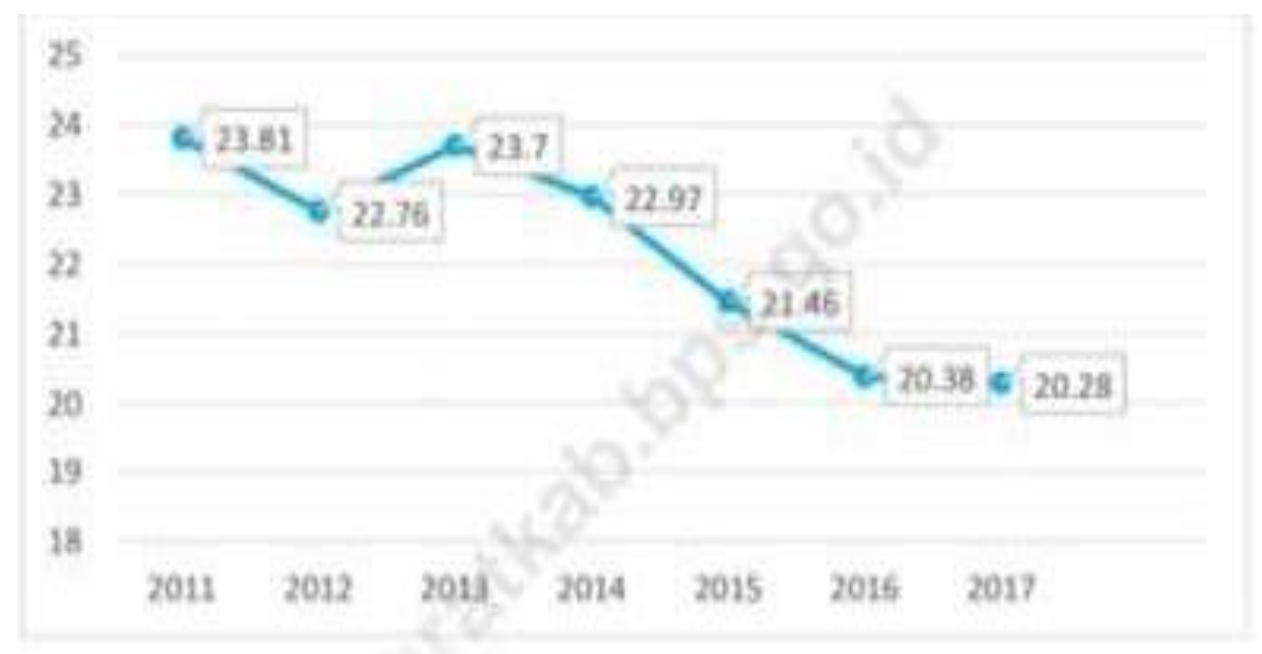

Gambar 2. Persentase penduduk miskin di Kabupaten Aceh Barat tahun 2011-2017 Sumber: Kabupaten Aceh Barat dalam Angka 2018 (BPS)

Berdasarkan data diatas menunjukkan angka kemiskinan di tahun 2016 sebanyak 20,38\% dan tahun 2017 20.28\% tidak turun secara signifikan.

Pelaksanaan Peraturan Bupati Aceh Barat Nomor 27 tahun 2017 ini memberi makna dan ruang lingkup kajian yang cukup kompleks. Dari beberapa kajian tersebut terdapat pendekatan-pendekatan yang efektif dan populer dikalangan masyarakat akademik berdasarkan konsep-konsep Van Meter dan Van Horn yang meliputi standar dan sasaran kebijakan, sumber daya kebijakan, komunikasi antar organisasi terkait dan kegiatan pelaksana, karakteristik agen pelaksana, kondisi ekonomi, sosial, dan politik serta sikap pelaskana atau disposisi 
implementor (Agustino, 2006).

$$
\text { Peraturan Bupati Aceh Barat }
$$

Nomor 27 Tahun 2017 tentang Pedoman Pemberdayaan Ekonomi Masyarakat melalui Dana Desa dimaksudkan sebagai salah satu langkah strategis untuk memenuhi penggunaan prioritas dana gampong sesuai arah kebijakan pemerintah kabupaten dan amanat dari Peraturan Menteri Desa Pembangunan Daerah Tertinggal dan Transmigrasi Nomor 22 Tahun 2016 tentang Prioritas Penggunaan Dana Desa Tahun 2017, disebutkan bahwa memberikan acuan bagi Pemerintah Kabupaten/Kota dalam menyusun pedoman teknis penggunaaan dana desa. Adapun sasaran kegiatan pemberdayaan ekonomi ini adalah masyarakat miskin, kaum disabilitas atau cacat fisik, kaum perempuan, masyarakat yang belum memiliki pekerjaan tetap dan masyarakat yang telah memiliki usaha yang tujuannya untuk meningkatkan pendapatan masyarakat gampong, menurunkan jumlah penduduk miskin, menurunkan angka pengangguran, meningkatkan pengetahuan, keterampilan, sikap dan perilaku masyarakat, meningkatkan produktivitas dan daya saing usaha masyarakat, mempersiapkan kader sumberdaya manusia yang handal dan terlatih serta meningkatkan pendapatan asli gampong.

Berikut ini nama-nama penerima bantuan modal pemberdayaan ekonomi di Gampong Leuhan, Gampong Padang Seurahet dan Gampong Blang Beurandang.
Dalam melaksanakan Peraturan Bupati Aceh Barat Nomor 27 tahun 2017 tentang pedoman pemberdayaan ekonomi masyarakat melalui dana desa di Kecamatan Johan Pahlawan (Gampong Leuhan, Padang Seurahet dan Blang Beurandang) anggaran yang digunakan bersumber dari Anggaran Pendapatan Belanja Gampong. Berdasarkan hasil temuan peneliti bahwa rata-rata tiga gampong ini menganggarkan 150 juta untuk kegiatan pemberdayaan ekonomi tersebut. 120 juta disalurkan kepada masyarakat penerima manfaat rata-rata masyarakat menerima 2 juta, ada yang 3 juta paling tinggi 5 juta disesuaikan dengan kebutuhan dan jenis usaha yang dijalankannya. Kemudian 30 juta nya lagi di gunakan sebagai biaya operasional seperti honorium tim verifikasi pemberdayaan, alat tulis kantor, fotocopy, cetak dan pengadaan, makan dan minum kegiatan rapat, perjalanan dinas dalam rangka survey atau pemantauan dan lainnya termasuk biaya sarana dan prasarana yang dibutuhkan serta kegiatan pelatihan dalam menunjang kegiatan pemberdayaan. Hal ini juga telah dijelaskan di dalam Perbub pada pasal 4 ayat 2 dimana sekurang-kurangnya sepuluh persen untuk operasional dan sepuluh persen nya lagi untuk pelatihan masyarakat setara dengan 30 juta sedangkan delapan puluh persen digunakan untuk bantuan modal pemberdayaan ekonomi masyarakat atau setara dengan 120 Juta.

Kegiatan pemberdayaan ekonomi 
ini sebenarnya perangkat gampong memberikan bantuan kepada penerima manfaat dalam bentuk barang dan angsurannya dikembalikan dalam bentuk uang namun perangkat gampong mengambil keputusan lain untuk menghindari hal-hal yang tidak diingkan seperti penyalahgunaan terhadap pembelian barang penerima manfaat.

Dari segi sumber daya waktu ratarata gampong melaksanakannya satu tahun sekali atau 12 bulan mulai dari penerimaan proposal dari masyarakat yang belum memperoleh bantuan pemberdayaan sampai pencairan uang gampong yang dianggarkan dalam Anggaran Pendapatan Belanja Gampong (APBG) termasuk angsuran cicilan dari masyarakat penerima manfaat harus dilunaskan dalam jangka waktu satu tahun itu, hal ini didasari atas musyawarah dan kesepakatan antara perangkat gampong dengan masyarakat penerima manfaat pemberdayaan ekonomi.

Kondisi ekonomi Kabupaten Aceh Barat, Kecamatan Johan Pahlawan tepatnya pada Gampong Leuhan mayoritas sebagai buruh tani, Gampong Padang Seurahet mayoritas berpenghasilan sebagai nelayan dan Gampong Blang Beurandang mayoritas bekerja disektor pertanian sehingga masih banyak terdapat masyarakat yang kurang mampu, pengangguran dan tidak mempunyai pekerjaan tetap. Dalam hal ini masyarakat kurang mampu pada Gampong Leuhan itu berjumlah 242 KK miskin, Gampong
Padang Seurahet 185 KK miskin dan Blang Beurandang 144 KK miskin.

Melihat kondisi tersebut pelaksanaan kegiatan pemberdayaan ekonomi masyarakat melalui dana desa ini tentu saja mendapat tanggapan dan respon yang sangat baik dari masyarakat, sehingga masyarakatnya sangat antusias berpartisipasi dalam kegiatan pemberdayaan ekonomi tahun 2017. Dari keseluruhan penerima bantuan pemberdayaan ekonomi di masing-masing Gampong yaitu pada Gampong Leuhan 46 orang, Padang Seurahet ada 53 orang dan Blang Beurandang 47 orang mayoritasnya sudah layak menerima bantuan modal pemberdayaan ekonomi, dikarenakan mayoritas pekerjaan dan pendapatannya terbilang masih rendah berkisaran 500.000 hingga $\mathbf{1 . 5 0 0 . 0 0 0}$ perbulan. Penerima bantuan tersebut sebagian sudah menjalankan usahanya walaupun tidak mempunyai keuntungan yang besar dan sebagiannya lagi ada yang tidak menjalankan usahanya karena sebagian penerima tidak menggunakan dana bantuan ekonomi tersebut untuk pemberdayaan digunakan untuk hal lain, kemudian faktor modal usaha yang masih kurang serta penerima bantuan pemberdayaan tidak ahli didalam bidang usaha yang dijalaninya.

Jika dilihat dari segi politik di Kabupaten Aceh Barat sampai ke tingkat gampong masih belum kondusif akibat pasca pemilu yang terjadi pada tahun 2017 dimana pergantian bupati baru berdampak kepada seluruh 
pemerintahan gampong yang ada di Kabupaten Aceh Barat termasuk pada Gampong Leuhan, Padang Seurahet dan Blang Beurandang mereka di turunkan dari jabatannya, rata-rata yang menduduki jabatan di pemerintahan gampong sejak pertengahan tahun 2017 hingga sekarang adalah tim kemenangan Bupati Aceh Barat pada periode kali ini. Hal tersebut didasari atas informasi dari informan dan faktafakta yang menunjukkan dilapangan sehingga pelaksanaan pemberdayaan ekonomi masyarakat melalui dana desa ditahun 2017 tidak berjalan lagi sampai dengan saat ini.

\section{SIMPULAN}

Pelaksanaan Peraturan Bupati Aceh Barat Nomor 27 Tahun 2017 tentang Pedoman Pemberdayaan Ekonomi Masyarakat melalui Dana Desa di Kecamatan Johan Pahlawan terutama pada Gampong Leuhan, Gampong Padang Seurahet, dan Gampong Blang Beurandang sudah dilaksanakan sesuai dengan ketentuan Peraturan Bupati Aceh Barat Nomor 27 Tahun 2017. Hal ini dibuktikan dengan terlaksananya 2 (dua) indikator kebijakan, yaitu penyaluran dana bantuan pemberdayaan dari perangkat gampong kepada masyarakat sesuai dengan standar dan tujuan kebijakan, serta sumber daya manusia dan anggarannya sudah memadai sehingga respon dari masyarakat sangat antusias terhadap kegiatan pemberdayaan ekonomi masyarakat melalui dana desa.

\section{DAFTAR PUSTAKA}

Agustino, L. (2006). Implementasi Kebijakan Public Mode Vann Meter Van Horn: The Implementation Policy Process. Bandung: CV Alfabeta.

Chambers, R. (1995). Pembangunan Desa: Mulai Dari Belakang. Jakarta: LP3ES.

Harahap, E. F. (2012). Pemberdayaan Masyaarakat dalam Bidang Ekonomi untuk Mewujudkan Ekonomi Nasional Yang Tangguh dan Mandiri. Jurnal Manajemen Dan Kewirausahaan, 3(2), 78-96.

Karimah, Faizatul; Saleh, Kahirul ; Wanusmawatie, I. (2017). Pengelolaan Alokasi Dana Desa dalam Pemberdayaan Masyarakat. Jurnal Administrasi Publik (JAP), 2(4), 597-602.

Purwanto, E. A. (2007). Mengkaji Potensi Usaha Kecil dan Menengah (UKM) untuk Pembuatan Kebiiakan Anti Kemiskinan di Indonesia. Jurnal IImu Sosial Dan IImu Politik, 10(3), 295-324.

Suharto, E. (2005). Membangun Masyarakat, Memberdayakan Rakyat: Kajian Strategis Pembangunan Kesejahteraan Sosial dan Pekerjaan Sosial. Bandung: Refika Aditama. 